\title{
Studies on Thrust Characteristic of High-Thrust Spiral Motor
}

\author{
Tsutomu Kominami Student Member (Yokohama National University) \\ Yasutaka Fujimoto Member (Yokohama National University)
}

Keywords: spiral motor, tubular type linear motor, PM motor

Linear actuators are used in various industrial applications. Conventional linear actuators are a combination of a rotational motor and a ball screw, a hydraulic actuator, or a linear motor. However, these actuators have some demerits. This paper proposes a spiral motor (SPRM) that comprises a spiral stator and a spiral mover. Owing to its spiral structure, the SPRM can be expected to show better performance as compared to the conventional linear actuator.

A stator and mover are shown in Fig. 1 and Fig. 2, respectively. Helical motion is obtained by this motor and only linear motion is extracted by cancelling rotational motion at the end effector. There are two types of SPRMs. One has no ball screw on the output axis, while the other has a ball screw. The former can be used in a direct drive system. However, the gap between the stator and the mover should be controlled because the motor is a magnetic levitation system without a ball screw. Further, the motor requires two threephase inverters. The other motor is easy to control because it does not require gap control. However, the motor is inferior to the first motor with regard to position control since the friction in this motor is larger.

In this study, a prototype of the SPRM is developed. The prototype constructed is a motor with a ball screw. In this motor, the stator and mover are made of block cells. The stator block is shown in Fig. 3 and the mover block is shown in Fig. 4. The prototype of the SPRM shown in Fig. 5, is developed by using these two blocks.

An experiment is conducted to examine the driving of the SPRM. The experimental result is shown in Fig. 6. From this result, it is evident that a comprising a spiral stator and a spiral mover can generate linear motion.

Another experiment is conducted for measuring the thrust characteristic of the motor. The result obtained is shown in Fig. 7. From

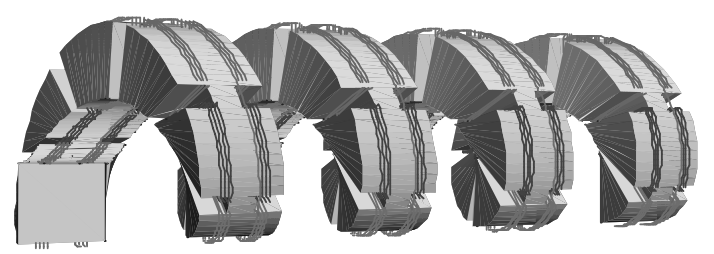

Fig. 1. Stator of the spiral motor

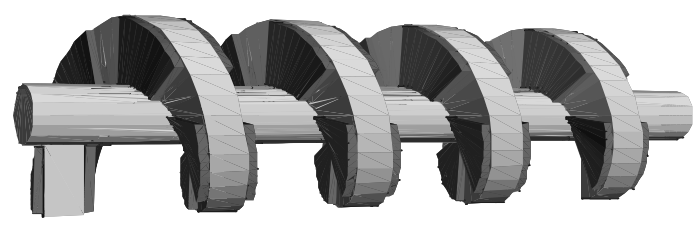

Fig. 2. Mover of the spiral motor the figure, the thrust constant of the spiral motor, $K_{f}$, is obtained as 538.0 [N/A].

This study was partly supported by the Industrial Technology Research Grant Program (Project ID: 05A48701d) of the New Energy and Industrial Technology Development Organization (NEDO), Japan.

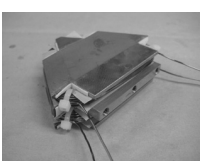

Fig. 3. Stator block

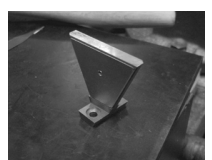

Fig. 4. Mover block

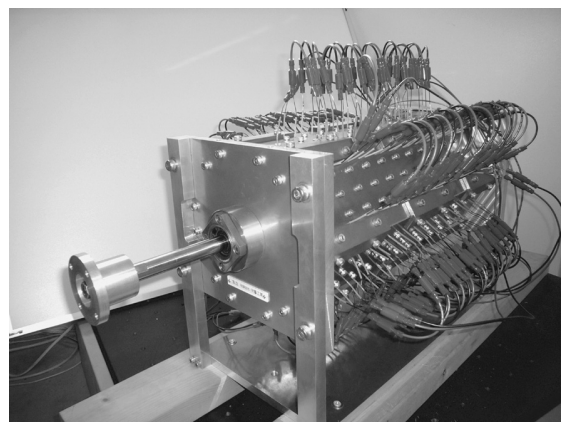

Fig. 5. Prototype of the spiral motor

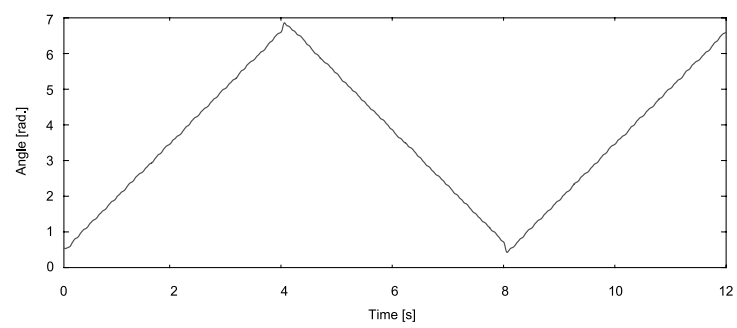

Fig. 6. Mover angle

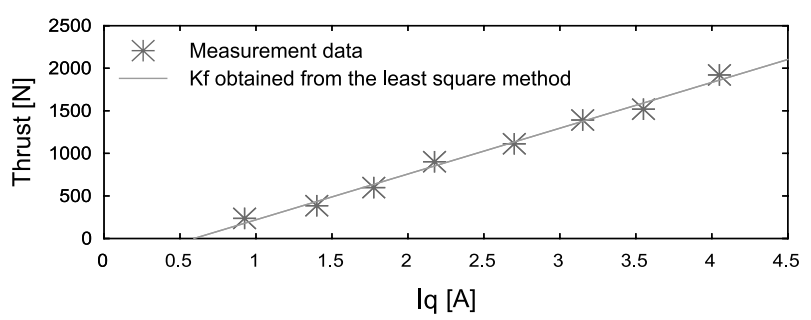

Fig. 7. Thrust characteristic 


\title{
高推力スパイラルモータの推力特性の検討
}

\author{
学生員 小南 勉* 正 員 藤本 康孝*
}

\author{
Studies on Thrust Characteristic of High-Thrust Spiral Motor
}

Tsutomu Kominami*, Student Member, Yasutaka Fujimoto*, Member

\begin{abstract}
Linear actuators are used in various industrial applications. Connentional linear actuators are a combination of a rotational motor and a ball screw, a hydraulic actuator, or a linear motor. However, these actuators have some demerits. This paper proposes a spiral motor (SPRM) that comprises a spiral stator and a spiral mover. Owing to its spiral structure, the SPRM can be expected to show better performance as compared to the conventional linear actuator. However, it is not easy to manufacture spiral stators and spiral movers. In this paper, thrust and torque equations derived from a magnetic circuit are introduced. A prototype is developed and its specifications are provided. Sixty fan-shaped stator blocks are mounted on the frame and forty-eight fan-shaped mover blocks with flat surfaces are mounted on the axis. These blocks form an approximately spiral structure. The blocks are not difficult to manufacture. The feasibility of the developed SPRM is confirmed by performing basic experiments. First, the SPRM is driven by using synchronous control. Subsequently, the thrust is measured by a load cell and the thrust constant is determined.
\end{abstract}

キーワード : スパイラルモータ, 円筒型リニアモータ, PM モータ

Keywords: spiral motor, tubular type linear motor, PM motor

\section{1. まえがき}

プレス機, 射出成形機, XY ステージ等の産業機器や, 自動 車に用いられているパワーステアリング等には直線運動型 のアクチュエータが広く用いられている。直動型アクチュ エータには, 油圧・空圧アクチュエータ, 回転型モータ+ 運動変換機構,リニアモータなどの種類がある。油圧・空 圧アクチュエータは保守性や制御性が低く，また電動モー 夕を利用したものは単体で大推力化が難しい。近年，保守 性の観点から油圧から電動アクチュエータへの置き換えが 進んでいる。しかし，電動モー夕単体で大きな力を発生さ せることは難しいため, 減速器および回転一直線運動変換機 構と組み合わせて実現されており, 装置が大型化・複雑化 するという問題がある。また，リニアモータは機械的変換 機構が不要で, モー夕単体で推力を発生させることができ るダイレクトドライブシステムであり，制御性に優れると いう利点がある。しかし，大推力化するためには装置のサ イズを拡大する必要があり, 大推力化が難しいという問題 がある。以上の理由から近年新しい直動型アクチュエータ が研究されており (1) (4), 中でも大きな推力が得られる円筒

\footnotetext{
* 横浜国立大学

干 240-8501 横浜市保土ヶ谷区常盤台 79-5

Yokohama National University

79-5, Tokiwadai, Hodogaya, Yokohama 240-8501
}

型リニアモータの開発が盛んになっている(3)(4)。本論文で 提案するスパイラルモータは円筒型リニアモータの一種で ある。スパイラルモータは螺旋形状をした固定子・可動子 を持ち, 可動子が固定子の中を螺旋運動し, 直線運動のみ を取り出して利用するモータである。円筒型にすることに より，磁束を有効に使うことが可能となり出力重量比の高 い構造を構築することが可能となり，これまで FEM 等で の解析が行われてきた ${ }^{(5)}$ 。また, 駆動方式についても検討 されておりシミュレーションにおいて有用性が確認されて いる ${ }^{(6) \sim(8)}$ 。

\section{2. スパイラルモータの構造}

図 1 にスパイラルモータの固定子を, 図 2 に可動子を示 す。また，図 3 にスパイラルモータの断面図を示す。固定 子には三相巻線が 2 組, 表面・裏面に施されており, 可動 子には永久磁石が表面・裏面に施されている。固定子が雌 ネジ，可動子が雄ネジの形状をしており，可動子が固定子 の中をネジの要領で回転しながら直線運動をする。最終的 な出力はベアリングにより回転成分を取り除き, 直線運動 のみを取り出す。可動子の半径方向の支持はベアリングに よって支持される。軸方向の支持は固定子巻線によって発 生させる電磁力のみで支持するモデルと今回報告するボー ルネジによって支持するものの 2 つのデルがある。

〈2・1〉 ボールネジなしモデルボールネジなしのモ 
デルではギアを用いていないため完全なダイレクトドライ ブを実現することが可能であり柔軟な運動を実現すること ができる。2 組の固定子巻線をそれぞれ独立に制御するこ とにより固定子-可動子間のギャップを制御するため，三相 インバー夕を 2 台用いる。このため，スパイラルモー夕用 インバータとして，三相インバータを 2 台用いたときより もパワーデバイスの総数を減らすことが可能なインバー夕 の開発を並行して行っている(8) (11)。このモデルに扔ける推 力 $f[\mathrm{~N}]$, トルク $\tau[\mathrm{N} \cdot \mathrm{m}]$ の理論式を導出する。

$\langle\mathbf{2 \cdot 2 \rangle}$ 推カ・トルクの理論式 (7) 図 4 にスパイラル モー夕の極座標展開図を, 図 5 に図 4 を元に求められる等 価磁気回路を示す。回路中において $\Phi$ は磁束を， $R$ は磁気 抵抗， $F_{m}$ は永久磁石による起磁力を表す。詳細は表 1 に 示す。ここで， $i$ は図 4 に示す領域 (i), (ii), (iii) に対応す る。 $j$ は永久磁石番号を表し, $x$ 軸正に磁束が向くものを 1 とし，逆向きを 2 とした。等価磁気回路より各領域に鎖交 する磁束 $\left(\Phi_{1}, \Phi_{2}, \Phi_{3}, \Phi_{1}{ }^{\prime}, \Phi_{2}{ }^{\prime}, \Phi_{3}{ }^{\prime}\right)$ を求め, 螺旋の 層数を考慮することにより各相の磁束は以下のように表わ される。これらの式に扔ける変数は表 2 に示す。

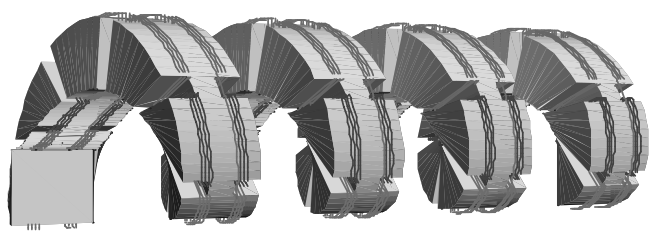

図 1 スパイラルモータの固定子

Fig. 1. Stator of the spiral motor.

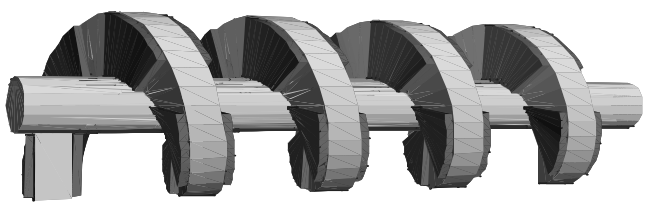

図 2 スパイラルモータの可動子

Fig. 2. Mover of the spiral motor.

$$
\begin{aligned}
\Phi_{u}= & \frac{n S \mu_{0}}{p\left(\ell-x_{g}\right)}\left(F_{m} k \cos (p \theta)+\frac{n}{3} I_{u}\right) \ldots \ldots \ldots \ldots \\
\Phi_{v}= & \frac{n S \mu_{0}}{p\left(\ell-x_{g}\right)}\left(F_{m} k \cos \left(p \theta-\frac{2 \pi}{3}\right)+\frac{n}{3} I_{v}\right) \ldots \ldots \\
\Phi_{w}= & \frac{n S \mu_{0}}{p\left(\ell-x_{g}\right)}\left(F_{m} k \cos \left(p \theta-\frac{4 \pi}{3}\right)+\frac{n}{3} I_{w}\right) \ldots \ldots \\
\Phi_{m}= & \frac{n S \mu_{0}}{p\left(\ell-x_{g}\right)}\left(\frac{\alpha}{2 \pi} F_{m}+n k\left(\cos (p \theta) I_{u}\right.\right. \\
& \left.\left.+\cos \left(p \theta-\frac{2 \pi}{3}\right) I_{v}+\cos \left(p \theta-\frac{4 \pi}{3}\right) I_{w}\right)\right) \\
\Phi_{u}{ }^{\prime}= & \frac{n S \mu_{0}}{p\left(\ell+x_{g}\right)}\left(F_{m} k \cos (p \theta)+\frac{n}{3} I_{u}{ }^{\prime}\right) \ldots \ldots \ldots \\
\Phi_{v}{ }^{\prime}= & \frac{n S \mu_{0}}{p\left(\ell+x_{g}\right)}\left(F_{m} k \cos \left(p \theta-\frac{2 \pi}{3}\right)+\frac{n}{3} I_{v}{ }^{\prime}\right) \ldots \ldots \\
\Phi_{w}{ }^{\prime}= & \frac{n S \mu_{0}}{p\left(\ell+x_{g}\right)}\left(F_{m} k \cos \left(p \theta-\frac{4 \pi}{3}\right)+\frac{n}{3} I_{w}{ }^{\prime}\right) \\
\Phi_{m}{ }^{\prime}= & \frac{n S \mu_{0}}{p\left(\ell+x_{g}\right)}\left(\frac{\alpha}{2 \pi} F_{m}+n k\left(\cos (p \theta) I_{u}{ }^{\prime}\right.\right. \\
& \left.\left.+\cos \left(p \theta-\frac{2 \pi}{3}\right) I_{v}{ }^{\prime}+\cos \left(p \theta-\frac{4 \pi}{3}\right) I_{w}{ }^{\prime}\right)\right)
\end{aligned}
$$

(1)（4) 式は図 5 中の領域 (A), (5)（8) 式は領域 (B) にお ける磁束を表す。

領域 (A) における磁気随伴エネルギー $W_{0}$, 領域 (B) にお ける磁気随伴エネルギー $W_{0}{ }^{\prime}$ は次式のように表わされる。

$$
\begin{aligned}
& W_{0}=\frac{1}{2}\left(I_{u} \Phi_{u}+I_{v} \Phi_{v}+I_{w} \Phi_{w}+I_{m} \Phi_{m}\right) \ldots \ldots \\
& W_{0}{ }^{\prime}=\frac{1}{2}\left(I_{u}{ }^{\prime} \Phi_{u}{ }^{\prime}+I_{v}{ }^{\prime} \Phi_{v}{ }^{\prime}+I_{w}{ }^{\prime} \Phi_{w}{ }^{\prime}+I_{m}{ }^{\prime} \Phi_{m}{ }^{\prime}\right)
\end{aligned}
$$

これより，全磁気随伴エネルギー $W$ は

$$
W=W_{0}+W_{0}{ }^{\prime} \cdot
$$

となる。この全磁気随伴エネルギーを可動子変位 $x_{g}[\mathrm{~m}]$ で

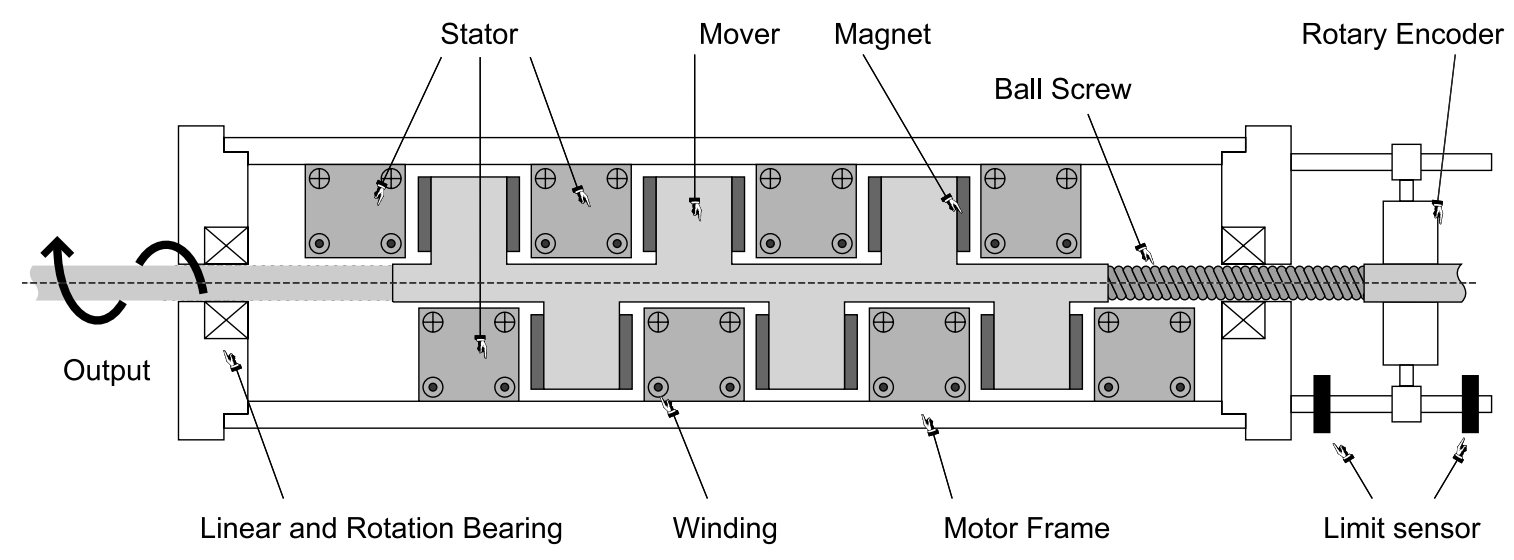

図 3 スパイラルモータの断面図

Fig. 3. Cut model of the spiral motor. 


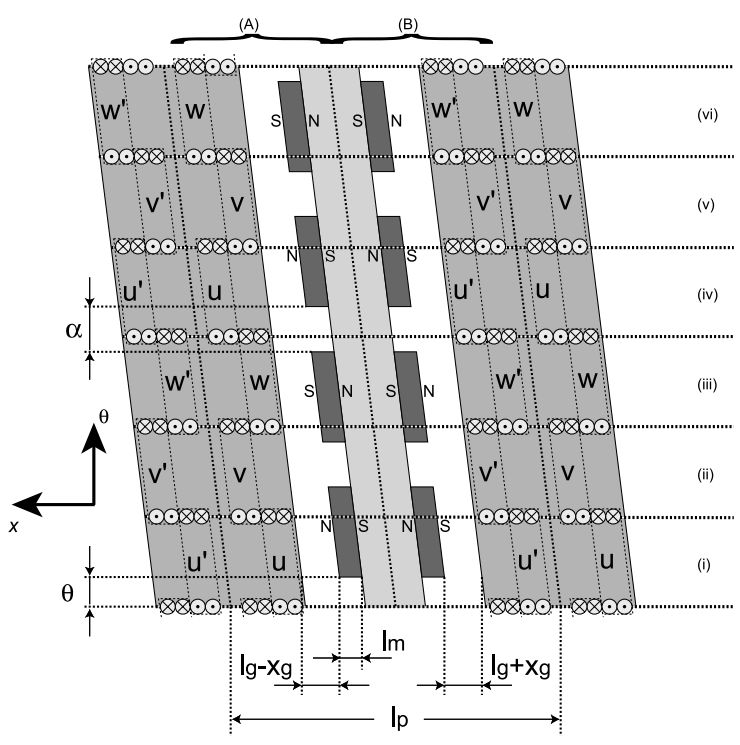

図 4 スパイラルモータの極座標展開図

Fig. 4. Polar-coordinate representation of spiral motor.

偏微分したものを推力，回転角 $\theta$ [rad.] で偏微分したものが トルクとなる。

$$
\begin{aligned}
& f=\frac{\partial W}{\partial x}=\mu q S\left(\frac{2 \alpha F_{m}^{2} \ell}{\pi\left(\ell-x_{g}\right)^{2}\left(\ell+x_{g}\right)^{2}} x_{g}\right. \\
& +\frac{2 n^{2}}{3}\left(\frac{I_{u}{ }^{2}+I_{v}{ }^{2}+I_{w}{ }^{2}+I_{u} I_{v}+I_{v} I_{w}+I_{w} I_{u}}{\left(\ell-x_{g}\right)^{2}}\right. \\
& \left.-\frac{I_{u}{ }^{2}+I_{v}{ }^{2}+I_{w}{ }^{\prime 2}+I_{u}{ }^{\prime} I_{v}{ }^{\prime}+I_{v}{ }^{\prime} I_{w}{ }^{\prime}+I_{w}{ }^{\prime} I_{u}{ }^{\prime}}{\left(\ell-x_{q}\right)^{2}}\right) \\
& +2 F_{m} k n\left(\frac{I_{u} \cos (p \theta)+I_{v} \cos \left(p \theta-\frac{2 \pi}{3}\right)+I_{w} \cos \left(\theta-\frac{4 \pi}{3}\right)}{\left(\ell-x_{g}\right)^{2}}\right. \\
& \left.\left.-\frac{I_{u}{ }^{\prime} \cos (p \theta)+I_{v}{ }^{\prime} \cos \left(p \theta-\frac{2 \pi}{3}\right)+I_{w}{ }^{\prime} \cos \left(\theta-\frac{4 \pi}{3}\right)}{\left(\ell+x_{g}\right)^{2}}\right)\right) \\
& \text {................ (12) } \\
& \tau=\frac{\partial W}{\partial x}=\frac{6 p q n S \mu k F_{m}}{\sqrt{3}}\left(\frac{I_{w} \cos \left(p \theta-\frac{2}{3} \pi\right)-I_{v} \cos \left(p \theta-\frac{4}{3} \pi\right)}{\ell-x_{g}}\right. \\
& \left.+\frac{I_{w}{ }^{\prime} \cos \left(p \theta-\frac{2}{3} \pi\right)-I_{v}{ }^{\prime} \cos \left(p \theta-\frac{4}{3} \pi\right)}{\ell+x_{g}}\right)
\end{aligned}
$$

ここで, $k$ は定数であり,

$$
k=\frac{2 \sqrt{3}}{\pi^{2}} \sin \frac{\alpha}{2}
$$

である。式中のパラメータを表 2 に示す。ここで推力の理 論式の第 1 項は，永久磁石と固定子鉄心の吸引力によって 発生するドリフト項である。この項は可動子が固定子間の 中央にある平衡状態のとき $x_{q}=0$ となるため零となる。第 2 項は固定子卷線電流と永久磁石によって発生する電磁力, また，第 3 項は固定子巻線電流と鉄心によって発生する電 磁力である。これらの理論式より，固定子巻線電流を表面・ 裏面逆位相で流すことによって推力が最大となり，表面・ 裏面同位相で流すことによってトルクが最大になることが

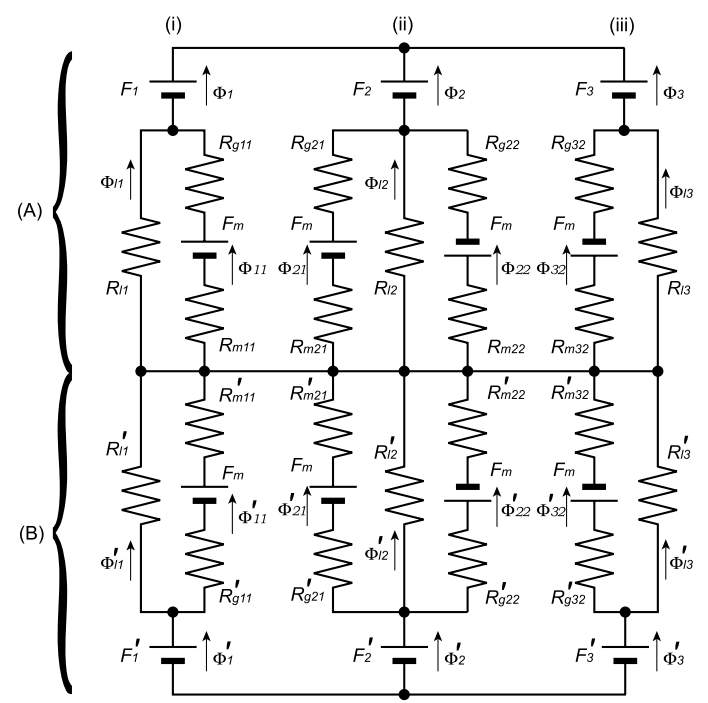

図 5 スパイラルモータの等価磁気回路

Fig. 5. Equivalent magnetic circuit.

表 1 等価磁気回路中のパラメータ

Table 1. Parameters of equivalent magnetic circuit.

\begin{tabular}{cc}
\hline$F_{m}[\mathrm{~A}]$ & $\begin{array}{c}\text { magnetomotive force of } \\
\text { permanent magnet }\end{array}$ \\
$F_{i}[\mathrm{~A}]$ & $\begin{array}{c}\text { magnetomotive force of windings } \\
\text { in } i \text { th domain }\end{array}$ \\
$R_{\ell i}[\mathrm{~A} / \mathrm{Wb}]$ & $\begin{array}{c}\text { magnetoresistance of leak } \\
\text { in } i \text { th domain }\end{array}$ \\
$R_{g i j}[\mathrm{~A} / \mathrm{Wb}]$ & $\begin{array}{c}\text { magnetoresistance of gap in } j \text { th } \\
\text { permanent magnet in } i \text { th domain } \\
\text { magnetoresistance of } \\
\text { permanent magnet }\end{array}$ \\
$R_{m i j}[\mathrm{~A} / \mathrm{Wb}]$ & $\begin{array}{c}\text { magnetic flux of winding } \\
\text { in } i \text { th domain } \\
\end{array}$ \\
$\Phi_{i}[\mathrm{~Wb}]$ & $\begin{array}{c}\text { magnetic flux of leak } \\
\text { in } j \text { th permanent magnet } \\
\Phi_{\ell i}[\mathrm{~Wb}]\end{array}$ \\
& $\begin{array}{c}\text { magnetic flux of } j \text { th permanent } \\
\text { magnet in } i \text { th domain }\end{array}$ \\
\hline$\Phi_{i j}[\mathrm{~Wb}]$ &
\end{tabular}

わかる。

ここで, (12), (13) 式を $d q$ 軸座標系で表すと次式のよう に表される。

$$
\begin{aligned}
& f=\frac{12 S \mu_{0} \ell F_{m}^{2}}{p\left(\ell-x_{g}\right)^{2}\left(\ell+x_{g}\right)^{2}} x_{g} \\
& +\frac{\sqrt{6} p K F_{m} I_{d}+2 n^{2} S \mu_{0}\left(I_{d}{ }^{2}+I_{q}^{2}\right)}{p\left(\ell-x_{q}\right)^{2}} \\
& -\frac{\sqrt{6} p K F_{m} I_{d}^{\prime}+2 n^{2} S \mu_{0}\left(I_{d}^{\prime 2}+I_{q}^{\prime 2}\right)}{p\left(\ell+x_{g}\right)^{2}} \\
& \tau=\frac{\sqrt{6} p K F_{m}}{\ell-x_{g}} I_{q}+\frac{\sqrt{6} p K F_{m}}{\ell+x_{g}} I_{q}^{\prime} \\
& {\left[\begin{array}{c}
I_{d} \\
I_{q}
\end{array}\right]=\sqrt{\frac{2}{3}}\left[\begin{array}{cc}
\cos (p \theta) & -\sin (p \theta) \\
\cos \left(p \theta-\frac{2}{3} \pi\right) & -\sin \left(p \theta-\frac{2}{3} \pi\right) \\
\cos \left(p \theta-\frac{4}{3} \pi\right) & -\sin \left(p \theta-\frac{4}{3} \pi\right)
\end{array}\right]^{T}\left[\begin{array}{c}
I_{u} \\
I_{v} \\
I_{w}
\end{array}\right]}
\end{aligned}
$$


表 2 式中のパラメータ

Table 2. Parameters of theoretical equations.

\begin{tabular}{|c|c|}
\hline$I_{u}, I_{v}, I_{w}[\mathrm{~A}]$ & $\begin{array}{l}\text { Current of } \mathrm{U}, \mathrm{V}, \mathrm{W} \text { phases } \\
\text { in frontal side of the stator }\end{array}$ \\
\hline$I_{u}^{\prime}, I_{v}^{\prime}, I_{w}^{\prime}[\mathrm{A}]$ & $\begin{array}{l}\text { Current of U', V', W' phases } \\
\text { in backside of the stator }\end{array}$ \\
\hline$\alpha[\mathrm{rad}]$ & $\begin{array}{l}\text { Angle between neighboring } \\
\text { permanent magnets }\end{array}$ \\
\hline$p$ & pair of poles \\
\hline$q$ & number of layers \\
\hline$l_{m}[\mathrm{~m}]$ & $\begin{array}{c}\text { Thickness of } \\
\text { a permanent magnet }\end{array}$ \\
\hline$l_{g}[\mathrm{~m}]$ & $\begin{array}{l}\text { Neutral gap length } \\
\text { between rotor and stator }\end{array}$ \\
\hline$x_{g}[\mathrm{~m}]$ & Displacement of gap \\
\hline$\theta[\mathrm{rad}]$ & Rotational angle of rotor \\
\hline$l_{p}[\mathrm{~m}]$ & Spiral pitch \\
\hline$n$ [times] & $\begin{array}{c}\text { Number of turns } \\
\text { per one slot of each phase }\end{array}$ \\
\hline$\mu_{0}[\mathrm{H} / \mathrm{m}]$ & Magnetic permeability of vacuum \\
\hline$\mu_{m}[\mathrm{H} / \mathrm{m}]$ & $\begin{array}{l}\text { Magnetic permeability } \\
\text { of permanent magnet }\end{array}$ \\
\hline$S\left[\mathrm{~m}^{2}\right]$ & $\begin{array}{c}\text { Facing area } \\
\text { between mover and stator for one pitch }\end{array}$ \\
\hline$B_{r}[\mathrm{~T}]$ & Residual flux density \\
\hline$F_{m}[\mathrm{~A}]$ & $\begin{array}{l}\text { Magnetomotive force } \\
\qquad\left(F_{m}=B_{r} l_{m} / \mu_{m}\right)\end{array}$ \\
\hline
\end{tabular}

ボールネジなしモデルでは，固定子巻線によってのみ軸 方向の負荷を支持する。負荷の変動は約 40\%の変化まで安 定化可能であることがシミュレーションによって確認され ている ${ }^{(8)}$ 。

〈2·3〉 ボールネジありモデルボールネジありのモデ ルでは可動子の動きがボールネジに拘束されるため, 前述 のボールネジなしのモデルに対し固定子一可動子間のギャッ プ制御が必要なくなる。これにより表面・裏面の巻線を 1 つの巻線として扱え，1つのインバータによって駆動する ことが可能となる。また実験機を製作するに際にもボール ネジありモデルの方が容易となる。今回報告する試作機で は可動子軸にボールネジを用いたモデルを採用した。本モ デルにおける推力 $f$ の理論式は，ボールネジによって固定 子一可動子間のギャップを固定することによりボールネジ なしモデルにおけるトルク分が推力に加わり次式のように 表される。

$$
\begin{aligned}
f & =f+\frac{2 \pi}{l_{p}} \tau \\
& =\frac{12 n p q \mu k \ell S \pi F_{m}}{\ell^{2} \ell_{p}} \cdot I_{q}=K_{f} \cdot I_{q} \ldots \ldots \ldots \ldots
\end{aligned}
$$

ここで $K_{f}$ は推力定数である。

\section{3. 試作機の開発}

螺旋形状を持つ固定子・可動子の製作するにあたり，積層 鋼板を螺旋状に積層する方法や柱材から螺旋形状を削り出 す方法の検討を行った。しかし，前者の方法では製作精度 が出ず可動子一固定子間のギャップが不均一になる，後者の
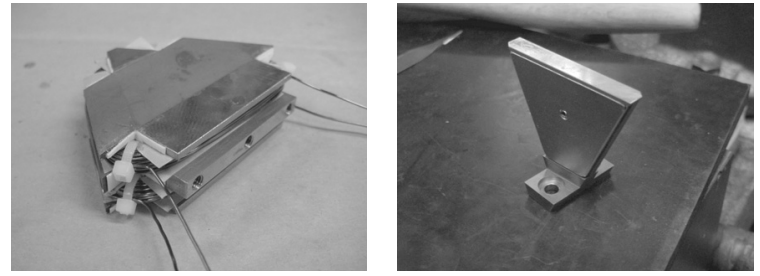

図 6 固定子ブロック (左), 可動子ブロック (右)

Fig. 6. Stator block (left) and mover block (right).

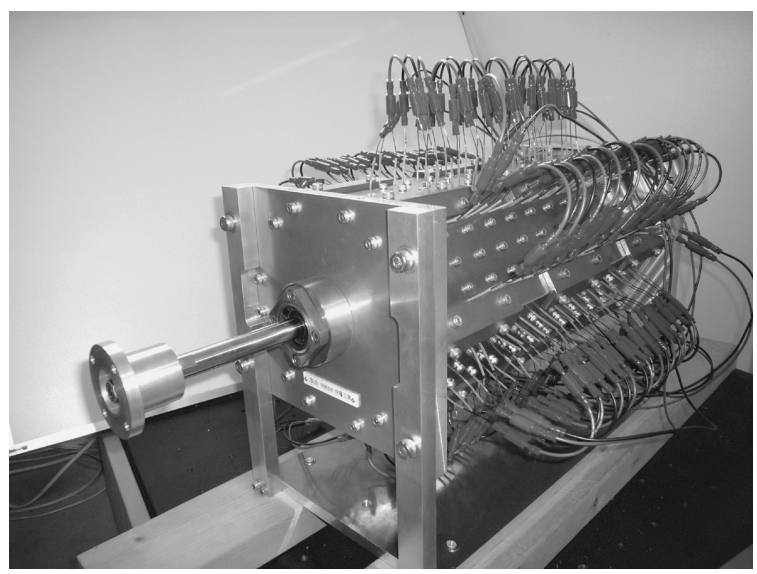

困 7 スパイラルモータの試作機

Fig. 7. Prototype of the spiral motor.

表 3 スパイラルモータの仕様

Table 3. Specifications of the spiral motor.

\begin{tabular}{cc}
\hline Size & $430[\mathrm{~mm}] \times \phi 180[\mathrm{~mm}]$ \\
Volume & $43[\mathrm{~kg}]$ \\
Stroke & $95[\mathrm{~mm}]$ \\
Spiral pitch & $30[\mathrm{~mm}]$ \\
Resistance of winding & $2.8[\Omega]$ \\
$d$-axis Inductance & $7.49[\mathrm{mH}]$ \\
$q$-axis Inductance & $7.82[\mathrm{mH}]$ \\
\hline
\end{tabular}

方法では同時 5 軸のマシニングセンタを使用することによ るコスト増大の問題があった, また, 永久磁石を螺旋曲面形 状に加工することも問題となった。そこで図 6 に示すよう に固定子・可動子をブロック状に分割製作し, 組み合わせ ることによって近似的に螺旋形状とした。固定子ブロック は厚さ $0.2[\mathrm{~mm}]$ の珪素鋼板をラジアル方向に積層して製作 した。可動子ブロックは切削により成形した。図 7 にスパ イラルモータ試作機を, 表 3 に試作機の仕様を示す。図 6 に示すように固定子は $\pi / 4$ [rad.], 可動子は $\pi / 3$ [rad.] のブ ロックで製作し, 複数個組み合わせることによって構成さ れる。本試作機では図 8 に示すように固定子 10 層, 可動子 6 層とした。分割して製作することによって多量のブロッ クが必要となり製造コストが増大するが, 分割コアにする ことによって高占積率で巻線を施すことが可能となる ${ }^{(12)}$ 。

出力軸の反対側にはエンコーダが取り付けられており回 転角を検知することが可能である。エンコーダは可動子と 共に移動し，リニアガイドによって支持されている。また， 


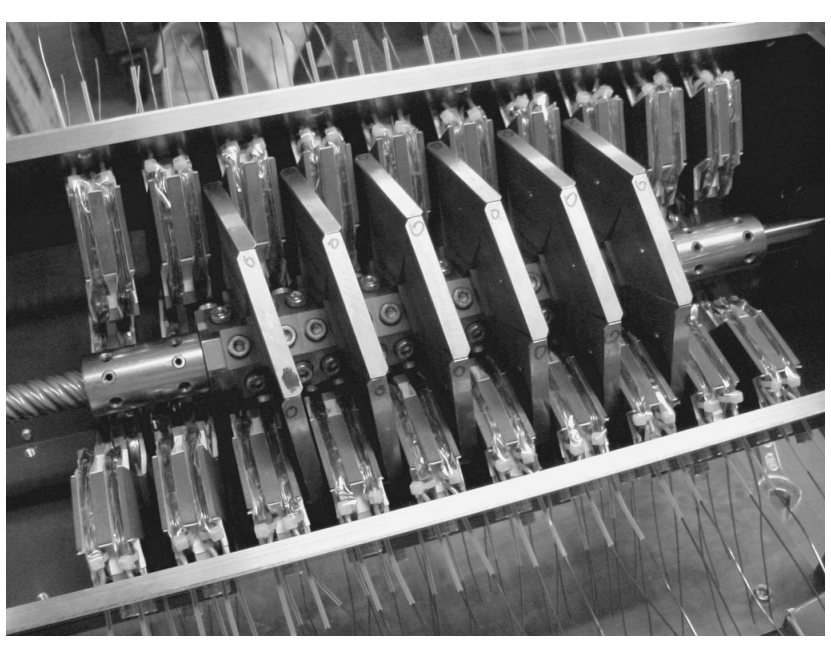

図 8 モー夕内部

Fig. 8. Interior of the spiral motor.

可動子の移動範囲に制限があるためリミットセンサを取り 付けている。

本試作機は $\mathrm{NdFeB}$ 磁石を表面に貼り付けた表面貼付型 永久磁石同期モー夕 $($ SPMSM）であるが, 固定子・可動子 をブロックにより構成するため図 8 に示すように完全な螺 旋構造とならず $d$ 軸， $q$ 軸インダクタンスに差が生じたと 考えられる。

\section{4. 実験}

図 9 に実験システムを示す。ボールネジありモデルであ るので固定子一可動子間のギャップを制御する必要がなく 三相インバー夕 1 台での駆動が可能である。可動子には可 動範囲に制限があるためリミットセンサが取り付けられて おり，リレーを介して保護回路を設置している。

可動子の前進・後進を 4 秒毎に切り替える指令值を与え たときの可動子角度を図 10 に，固定子巻線に流れる電流 波形を図 11 に示す。図 10 より，指令值通り前進・後進が 切り替わっていることがわかる。また，このとき電流值の 位相が反転していることが確認することができる。この実 験により，提案するスパイラル形状の固定子・可動子を持 つリニアモータで直線運動を出力可能であることが実証さ れた。

\section{5. 推力定数}

〈5・1 理 論 值 表 4 に示寸試作機のパラメータを (17) 式に代入すると,

$$
f=590.1 \cdot I_{q}
$$

となり，推力定数は 590.1 [N/A] である。

$\langle\mathbf{5} \cdot \mathbf{2}\rangle$ 実験による推力特性の測定＼cjkstart試験機にロード セルを取り付け推力特性を測定した。ロードセルには（株） 共和電業 LUX-A-5KN-P を用いた。出力軸とロードセルを 接触させた後， $\mathrm{q}$ 軸電流を変化させて推力の測定を行った。 図 12 に測定結果を示す。横軸に $\mathrm{q}$ 軸電流 [A] ととり, 縦軸

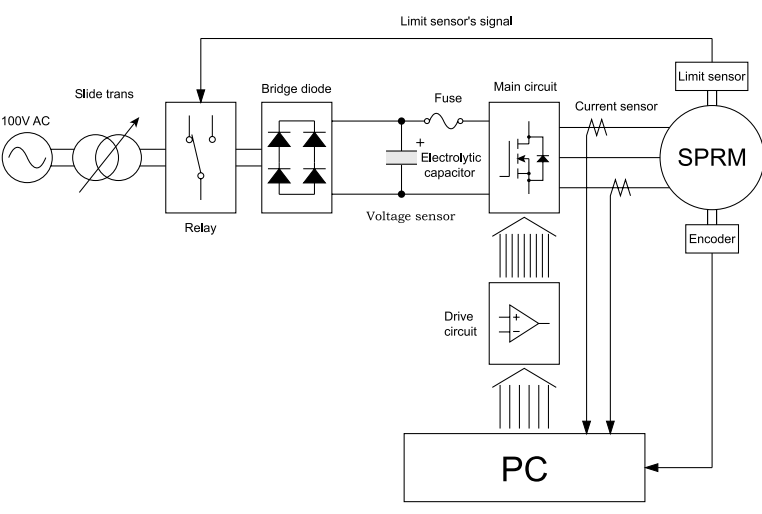

図 9 実験システム

Fig. 9. Experimental system.

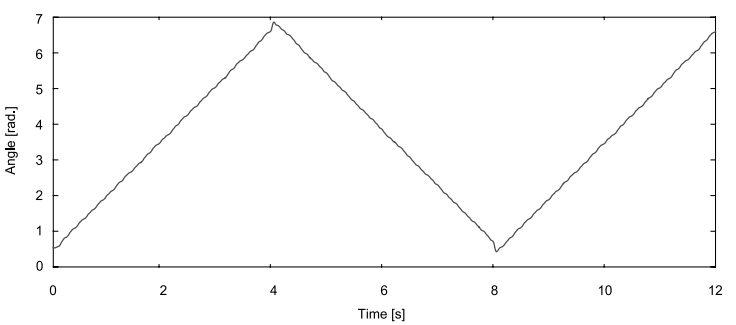

図 10 可動子の回転角

Fig. 10. Mover angle.

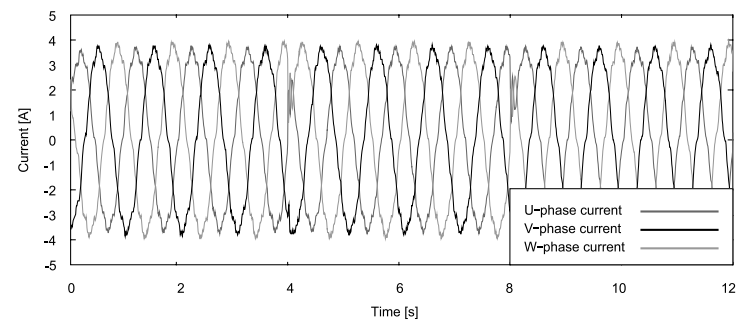

図 11 巻線電流波形

Fig. 11. Current of windings.

表 4 試作機のパラメータ

Table 4. Parameters of prototype spiral motor.

\begin{tabular}{cc}
\hline$n[$ turn $]$ & 39 \\
$p$ & 4 \\
$q$ & 6 \\
$\ell_{g}[\mathrm{~m}]$ & $2.0 \times 10^{-3}$ \\
$\ell_{m}[\mathrm{~m}]$ & $2.0 \times 10^{-3}$ \\
$\ell_{p}[\mathrm{~m}]$ & $30 \times 10^{-3}$ \\
$B_{r}[\mathrm{~T}]$ & 1.21 \\
$S\left[\mathrm{~m}^{2}\right]$ & $9.45 \times 10^{-3}$ \\
$\mu[\mathrm{H} / \mathrm{m}]$ & $4 \pi \times 10^{-7}$ \\
\hline
\end{tabular}

を推力 $[\mathrm{N}]$ とした。プロット点を最小二乗法により直線近 似し傾きを求めると, 推力定数 $K_{f}$ は $538.0[\mathrm{~N} / \mathrm{A}]$ となる。 実験により求めた推力定数と理論值はほぼ一致した。若干 の誤差は理論值を求めた際に鉄心の透磁率を無限大と仮定 したためだと考えられる。 


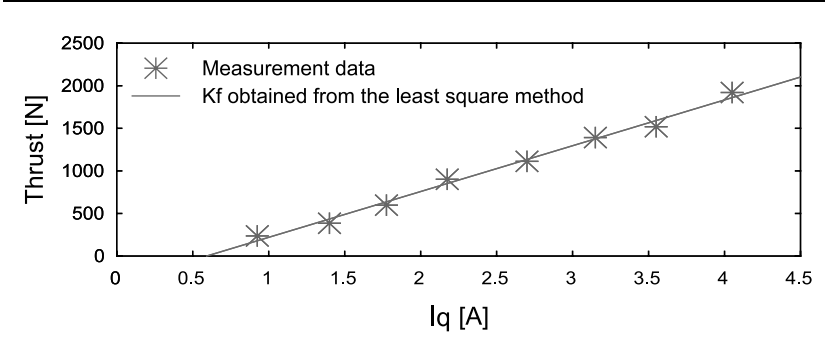

図 12 推力特性

Fig. 12. Thrust characteristic.

\section{6. まとめ}

新しい直動型アクチュエータであるスパイラルモータ試 作機の紹介をした。試作機を固定子, 可動子をブロックに 分けて製作し, 巻線抵抗, インダクタンス等の諸特性を測 定した。また, 推力特性を測定し, 推力定数を求めた。

本稿では, 螺旋型をした固定子・可動子によって直線運 動を取り出すことが可能であることの確認, 推力定数の測 定を行った。

今回製作した試作機はボールネジありモデルである。そ のため駆動の際に摩擦が生じる。しかし, 従来の回転型モー 夕の回転運動をボールネジを介して直線運動を取り出すも のはボールネジのベアリング部に片べりが生じていた。ス

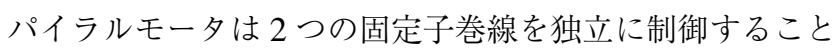
により直接螺旋運動を生成可能であり，片べりが生じない。 また，通常のリニアモータと比べて，構造上，トータルの 極対数を大きくとることができ，小型で大きな推力を得る ことができると考えられる。以上より摩擦によって位置決 め精度に影響が出るが，大きな推力を得られるため油圧ア クチュエー夕等を用いていたプレス機等に適用することが 可能であると考えられる。

\section{謝 辞}

最後に, 本研究の一部はNEDO 産業技術研究助成 (プロ ジェクト ID：05A48701d）拈よび科学研究費補助金（課題 番号：19676003）によって行われたことを付記する。

(平成 19 年 11 月 26 日受付, 平成 20 年 9 月 22 日再受付)

\section{文献}

( 1 ) J.-Y. Lee, J.-P. Hong, J.-H. Chang, and D.-H. Kang: "Computation of Inductance and Static Thrust of a Permanent-Magnet-Type Transverse Flux Linear Motor", IEEE Trans. on Industry Applications, Vol.42, No.2, pp.487-494 (2006-3/4)
(2) O. Ustun and R.N. Tuncay: "Design, Analysis, and Control of a Novel Linear Actuator", IEEE Trans. on Industry Applications, Vol.42, No.4, pp.1007-1013 (2006-7/8)

(3) N. Bianchi, S. Bolognani, D.D. Corte, and F. Tonel: "Tubular Linear Permanent Magnet Motors:An Overall Comparison", IEEE Trans. on Industry Applications, Vol.39, No.2, pp.466-475 (2003-3/4)

(4) Y. Amara, J. Wang, and D. Howe: "Stator Iron Loss of Tubular PermanentMagnet Machines", IEEE Trans. on Industry Applications, Vol.41, No.4, pp.989-995 (2005-7/8)

(5) H. Kwon and Y. Fujimoto: "Thrust Characteristic of High-Thrust Spiral Motor Using FEM Analysis", IEEJ Trans. on Industry Applications, Vol.127-D, No.6, pp.653-662 (2007-6)

(6) H. Kwon and Y. Fujimoto: "FEM Analysis of High Thrust Spiral Motor", IEEE International Workshop on Advanced Motion Control (2003)

(7) T. Kominami and Y. Fujimoto: "Dynamic model and Contorl of Six-Phase Spiral Motor", IEEE International Workshop on Advanced Motion Control (2003)

(8) T. Kominami and Y. Fujimoto: "Magnetic Levitation Control and SpiralLinear Transformation System for Spiral Motor", IEEE International Workshop on Advanced Motion Control, Vol.2, pp.529-534 (2006)

(9) T. Kominami and Y. Fujimoto: "Proposal of a Nine-Switch Inverter That Can Independently Control Two PM Motors", IEEJ Industry Applications Society Conference, pp.187-190 (2006) (in Japanese)

(10) T. Kominami and Y. Fujimoto: "Development of a Nine-Switch Inverter That Can Independently Control Two Loads", IEEJ Annual Meeting Record, pp.133-134 (2007) (in Japanese)

(11) T. Kominami and Y. Fujimoto: "A Novel Nine-Switch Inverter for Independent Control of Two Three-phase Loads", IEEE Industry Applications Society Annual Meeting (2007)

(12) Y. Enomoto, M. Kitamura, T. Sakai, and K. Ohara: "A Way to Select Electrical Sheets of the Segment Stator Core Motors", IEEJ Trans. IA, Vol.124, No.10, pp.1010-1016 (2004) (in Japanese)

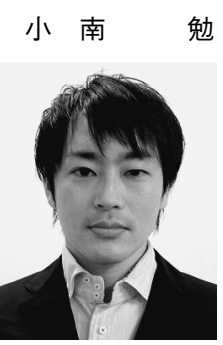

勉 (学生員) 2003 年 3 月横浜国立大学工学部電子 情報工学科卒業。2004 年 3 月同大学院物理情報 工学専攻電気電子ネットワークコース博士課程前 期修了。2004 年 4 月博士課程後期に入学, 現在 に至る。スパイラルモータ, パワーエレクトロニ クスの研究に従事。日本ロボット学会の会員。

藤 本 康 孝 (正員) 1993 年 3 月横浜国立大学工学部電子情

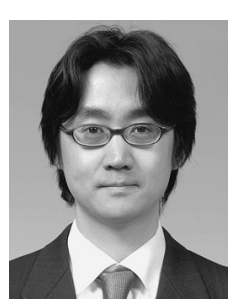
報工学科卒業。1998 年 3 月同大学院工学研究科 電子情報工学専攻博士課程修了。同年 4 月慶應義 塾大学理工学部嘱託助手。1999 年 4 月横浜国立 大学工学部電子情報工学科助手。2000 年 4 月同 講師。2002 年 4 月横浜国立大学大学院工学研究 院助教授, 現在に至る。博士 (工学)。システム 工学, ロボティクスの研究に従事。日本ロボット 学会, 計測自動制御学会, IEEE, INFORMS の会員。 